\title{
A Study on Selecting Green Indexes of a Seaport
}

\author{
Ji-Yeong Pak*, Gi-Tae Yeo ${ }^{\dagger}$, Byung-mo, Coo** \\ $*^{\dagger}, * *$ Graduate School of logistics, Incheon University, Incheon 408-840, Republic of Korea
}

\begin{abstract}
The aim of this study draws out the Green Index of a Seaport (GIS) that is comprehensive and coordinated approach to diminish the negative impacts of port operations using a Factor Analysis (FA) which can evaluate the level of cleanness of seaport. For this purpose, the questionnaires were sent to the experts and port stake holders, and received 75 out of 100. In this survey, Cronbach's alpha has the numerical value 0.76. Thus it means that this survey has internal consistency reliability. Overall, 15 components were selected from the literature review and five factors were extracted by factor analysis.
\end{abstract}

Key words : green port, green index, factor analysis, Cronbah's alpha

\section{Introduction}

As a result of industrialization and economic plans which emphasize the importance of an economic growth, an ecological system faces crisis of disruption. It is very important to be concerned about environment problems because environment problems are closely related to the right to live of mankind. The characteristics of industrial society are difficult to match well with the ecological system. The organizational contradiction of industrial society raises two problems. First, it is related to natural environment like air pollution, water pollution, an exhaustion of natural resources, the extinction of rare animals. The second is human environment or living environment like concentration of population, urbanization, the collapse of traditions and culture. (Jung, 2003)

In the case of a port, it is possible to affect the two aspects stated above. Therefore, the environmental problems in ports produce lots of interest concerning the way to reduce exposed problems. For this reason, numerous ports in the world have attempted to find and explore the way to run a more eco-friendly port.

Many main ports in the world have set to work in order to preserve the environment of a port as sustainable competitiveness. For examples, Japan has already started eco-port policies and the port of Rotterdam in Netherlands has stressed the efforts to preserve port environment under the name of 'Green Award'. In long beach port, America also set to new policy concerned green port. The policy's five guiding principles are: (1) Protect the community from harmful environmental impacts of Port operations, (2) Distinguish the Port as a leader in environmental stewardship and compliance. (3) Promote sustainability. (4) Employ best available technology to avoid or reduce environmental impacts. (5) Engage and educate the community. Based on these trends, it is necessary to establish new green port index as a part of a standard. With this consideration, this paper should like to deduce port evaluation indexes. These. indexes have not existed yet. However, as the expectation about a new role of a port increases, the importance of evaluation standard like green port index will also increase.

In this overall perspective, Korea should follow the green port trend. Korea has greatly developed ports as well as many other industries, but the field of green ports is relatively young and, as such, is still establishing its basic concepts in Korea. Moreover, to keep face with the recent trend of a port, green port indexes will help the port upgrade its level.

Thus, this paper suggests a port pollution factor and addresses the green indexes for a green port using well known methodology factor analysis.

\section{Literature review}

In recent years, some studies have attempted to examine eco-friendly port. Environmental concerns in a port given by Bailey(2004) are air pollution from port operations, loss or

\footnotetext{
* assambleuse@hanmail.net 032)835-4590

† Corresponding author : Gi-Tae Yeo, ktyeo@incheon.ac.kr 032)835-8196

**Keironcoo@paran.com 032)835-4590
} 
degradation of wetlands, destruction of fisheries and endangered species, severe traffic congestion, noise and light pollution, loss of cultural resources, contamination of soil and water from leaking storage tanks, air release from chemical storage or fumigation activities, solid and hazardous waste generation, and soil runoff and erosion.

The amount of research on the green port components have been conducted on the idea that the factor of a green port is related to air pollution. Air pollution is able to cause pecuniary problem related to $\mathrm{CO} 2$ reduction of Kyoto protocol, which has the purpose of preventing global warming. However, generally the most mentioned factors are divided into water pollution, air pollution, noise, ecology, waste management. These large group factors are divided into separate sub-categories.

Song and Han(2007) study indicates components like replace old engine with new and efficient engine, cold ironing(power supplier from inland), use of clean fuels, pollutant control from oceangoing ships, changing outworn equipment.

At the same time, to prevent environmental pollution by operating and developing ports, there are necessities to establish the basic policies and the environmental policies during planning, construction, and operation. At the planning stage, it is important to strengthen environmental impact assessment and at the stage of construction, to minimize noise, water pollution, dust scattering and at the stage of operation, to elicit the operation strategies for a standard of natural environment legislation and try to minimize environmental damage(Song, 2000). Literature review is shown Table1.

Table 1 Literature review of the components of eco-friendly port

\begin{tabular}{l|l}
\hline \multicolumn{1}{c|}{ Author(date) } & \multicolumn{1}{c}{ Components } \\
\hline \hline & $\begin{array}{l}\text { Air pollution from port operations, including smog } \\
\text { and particulate pollution, Loss or degradation of } \\
\text { wetlands, Destruction of fisheries and endangered } \\
\text { species, Wastewater and storm water discharges, } \\
\text { Severe traffic congestion, Noise and light } \\
\text { Giane Bailey, } \\
\text { (2004) }\end{array}$ \\
$\begin{array}{l}\text { pollution, Loss of cultural resources, Contamination } \\
\text { of soil and water from leaking storage tanks, Air } \\
\text { releases from chemical storage or fumigation } \\
\text { activities, Solid and hazardous waste generation, } \\
\text { Soil runoff and erosion }\end{array}$ \\
$\begin{array}{l}\text { Song, Gye-Eui } \\
\text { \&Han,Chul Hwan } \\
\text { (2007) }\end{array}$ & $\begin{array}{l}\text { Cold ironing of engine with new one } \\
\text { Use of clean fuel } \\
\text { Pollutant control from oceangoing ships } \\
\text { Changing wornout equipment }\end{array}$ \\
\hline $\begin{array}{l}\text { Song, } \\
\text { Man-Soon } \\
\text { (2000) }\end{array}$ & $\begin{array}{l}\text { Port environmental plan, } \\
\text { Environmental impact assesment } \\
\text { Monitoring system }\end{array}$ \\
\hline $\begin{array}{l}\text { Hyun-dai } \\
\text { engineering } \\
\& \text { construction } \\
\text { (2008) }\end{array}$ & $\begin{array}{l}\text { CO reduction- AMP(Alternative } \\
\text { Maritime Power), } \\
\text { DPF(Diesel Particulate Filter trap), e-RTGC, } \\
\text { CNG(Compressed Natural Gas), } \\
\text { Bio-Diesel, hydrogen fuel }\end{array}$ \\
\hline
\end{tabular}

\section{Empirical analysis}

\subsection{Factor analysis}

This paper draws on a factor analysis of SPSS to examine the factors that have an effect on selecting green port indexes. Factor analysis is used to reveal the hidden dimensions of a set of variables. It diminishes attributes from a larger number of variables to smaller number of factors by collecting similar items. In this paper, the data reduction uses principal component analysis among lots of methods and to convert the factor matrix into the easy figure that uses Varimax method among orthogonal rotation method. Principal Components Analysis is a method which reduces data dimensionality by executing a covariance analysis between factors. As such, it is suitable for data sets in multiple dimensions, such as a large experiment in gene expression. And Varimax rotation is a method for rotating axes of a plot such that the eigenvectors remain orthogonal as they are rotated. These rotations are used in principal component analysis so that the axes are rotated to a position in which the sum of the variances of the loadings is the maximum possible.

The data reduction of these attributes is obtained by surveys of experts who are engaged in ports and shipping company. These experts made a survey to answer what is associated with selecting the factors of green port. The survey obtained 15 selected indexes by Literature Review (Table1) and was carried out by Llikert Scaling as shown below table2.

Survey was conducted from August 24, 2009 to September 21, 2009. The targets of the survey were port public corporations, shipping companies and global terminal operators. Detail ratio is shown fig.1.

\section{-Survey method}

(1) Date: Aug 24, 2009 - Sep 21, 2009

(2) Target: Port public corporations(34\%)

Shipping companies(40\%)

Global terminal operators(26\%)

(3) Distribution: 100 (collection : 75)

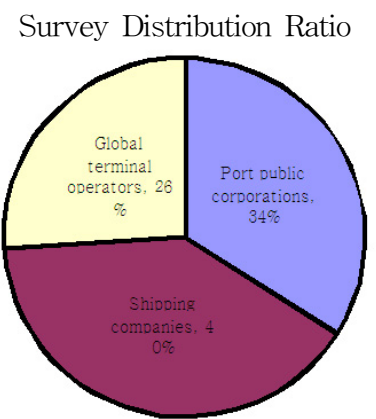

Fig. 1 Survey distribution ratio 
Table 2 Variables for factor analysis

\begin{tabular}{|c|c|}
\hline Variables & Description \\
\hline $\begin{array}{l}\text { Resources recycling inside a } \\
\text { port }\end{array}$ & $\begin{array}{l}\text {-Prevention of waste of resources } \\
\text {-Reduction of natural resources } \\
\text { usage. }\end{array}$ \\
\hline $\begin{array}{l}\text { Technical development of } \\
\text { industry \& the ocean waste } \\
\text { disposal }\end{array}$ & -A method of eco-friendly construction \\
\hline $\begin{array}{l}\text { Development of Breakwater } \\
\text { system of waterfront revitalization }\end{array}$ & $\begin{array}{l}\text {-Creation of a pleasant life } \\
\text { environment }\end{array}$ \\
\hline Dredging sand recycling & $\begin{array}{l}\text {-Utilization as a reclamation } \\
\text { material after solidification } \\
\text {-Using at artificial wetlands or } \\
\text { beach face development }\end{array}$ \\
\hline $\begin{array}{l}\text { Creation of artificial } \\
\text { sandbar \& wetland }\end{array}$ & $\begin{array}{l}\text {-A recovery of natural } \\
\text { purification of an ecosystem }\end{array}$ \\
\hline \begin{tabular}{l|l} 
Establishing Strategic Plan for & \\
Port environment \& & $\mathrm{r}$ \\
Introduction of environmental & $\mathrm{p}$ \\
impact assessment & $e$
\end{tabular} & $\begin{array}{l}\text {-Exploring every avenue about } \\
\text { reducing environmental effects by } \\
\text { predicting harmful effects on port } \\
\text { environment. }\end{array}$ \\
\hline Use of alternative fuels & $\begin{array}{l}\text {-Solar energy, Wind energy, tidal } \\
\text { energy and so on }\end{array}$ \\
\hline $\begin{array}{l}\text { Introduction of port } \\
\text { environment management system }\end{array}$ & $\begin{array}{l}\text {-Working in close cooperation } \\
\text { with companies \& administrative } \\
\text { agencies. }\end{array}$ \\
\hline $\begin{array}{l}\text { Port facilities \& equipment } \\
\text { improvement }\end{array}$ & $\begin{array}{l}\text {-AMP(Alternative Maritime Power) } \\
\text {-DPF(Diesel Particulate Filter trap) } \\
\text {-e-RTGC }\end{array}$ \\
\hline Incentives of pollution reduction & $\begin{array}{l}\text {-Incentives to shipping companies } \\
\& \text { stevedores with eco-friendly } \\
\text { equipment. }\end{array}$ \\
\hline Use of Renewable-energy & $\begin{array}{l}\text {-Use of CNG(Compressed Natural } \\
\text { Gas) } \\
\text {-Use of Bio-Diesel, hydrogen fuel }\end{array}$ \\
\hline Modal shift & $\begin{array}{l}\text {-Repair and maintenance a } \\
\text { harbor-side road \& Introduction of } \\
\text { new transportation modes. }\end{array}$ \\
\hline $\begin{array}{l}\text { Construction method of noise } \\
\text { reduction }\end{array}$ & $\begin{array}{l}\text {-Use of construction methods } \\
\text { for noise and vibration control } \\
\text {-Use of noise reduction equipment }\end{array}$ \\
\hline Efficient construction plan & -Eliminating unnecessary procedures \\
\hline $\begin{array}{l}\text { Expansion of the coastal region } \\
\text { facilities } \\
\text { (prevention of ocean pollution } \\
\text { caused by land activities) }\end{array}$ & $\begin{array}{l}\text {-Expansion and improve the } \\
\text { sewage disposal plants, sewage } \\
\text { landfills, waste water disposal } \\
\text { plants, and so on }\end{array}$ \\
\hline
\end{tabular}

\subsection{Application of factor analysis}

The Factor analysis is carried out with the indexes in Table 2 and extracts five components are listed in Table3.

Five factors can be an index of a green port and these five factors will offer further evidence of the purpose of this paper. In other words, these five extracted factors from 15 components can contribute to a more total understanding of the green port.
Table 3 Rotated component matrix

\begin{tabular}{|c|c|c|c|c|c|}
\hline & \multicolumn{5}{|c|}{ Component } \\
\hline & 1 & 2 & 3 & 4 & 5 \\
\hline $\begin{array}{l}\text { Use of alternative } \\
\text { fuels }\end{array}$ & .742 & .129 & -.082 & .051 & -.084 \\
\hline $\begin{array}{l}\text { Incentives } \\
\text { of pollution } \\
\text { reduction }\end{array}$ & .725 & -.005 & -.276 & .365 & .119 \\
\hline $\begin{array}{l}\text { Renewable-energy } \\
\text { using }\end{array}$ & .644 & .244 & .057 & -.090 & .384 \\
\hline $\begin{array}{l}\text { Dredging sand } \\
\text { recycling }\end{array}$ & .553 & .090 & .425 & .026 & .093 \\
\hline $\begin{array}{l}\text { Port facilities \& } \\
\text { equipment } \\
\text { improvement }\end{array}$ & .168 & .796 & -.109 & .065 & -.072 \\
\hline $\begin{array}{l}\text { Development of } \\
\text { Breakwater system } \\
\text { of waterfront } \\
\text { revitalization }\end{array}$ & .041 & .673 & .305 & .027 & .116 \\
\hline $\begin{array}{l}\text { Construction } \\
\text { method of noise } \\
\text { reduction }\end{array}$ & .283 & .521 & .229 & .178 & .237 \\
\hline $\begin{array}{l}\text { Technical } \\
\text { development of } \\
\text { industry\&the ocean } \\
\text { waste disposal }\end{array}$ & -.150 & .158 & .818 & .014 & -.063 \\
\hline $\begin{array}{l}\text { Resources recycling } \\
\text { inside a port }\end{array}$ & .040 & .030 & .795 & .262 & .028 \\
\hline $\begin{array}{l}\text { Introduction of port } \\
\text { environment } \\
\text { management system }\end{array}$ & -.011 & .474 & -.151 & .670 & -.100 \\
\hline $\begin{array}{l}\text { Expansion of the } \\
\text { coastal region } \\
\text { facilities }\end{array}$ & .042 & .189 & .306 & .657 & -.005 \\
\hline $\begin{array}{l}\text { Efficient } \\
\text { construction plan }\end{array}$ & .240 & -.172 & .248 & .651 & .152 \\
\hline Modal shift & .134 & -.055 & -.074 & -.062 & .844 \\
\hline $\begin{array}{l}\text { Establishing } \\
\text { Strategic Plan for } \\
\text { Port environment } \\
\text { \& Introduction } \\
\text { of environmental } \\
\text { impact assessment }\end{array}$ & .008 & .071 & -.044 & .519 & .572 \\
\hline $\begin{array}{l}\text { Creation of artificial } \\
\text { sandbar \& wetland }\end{array}$ & .043 & .459 & .168 & .128 & .565 \\
\hline
\end{tabular}

Extraction Method: Principal Component Analysis

Rotation Method: Varimax with Kaiser Normalization

By and large, it has a meaning as an identical factor when the figure of components is above 0.5. Each factor with the components above 0.5 is highly correlated and it can be explained as an identical factor.

In addition, in order to test a survey's internal consistency reliability, Cronbach's alpha is used. Cronbach's alpha is a 
method to asses the reliability of a rating summarizing a group survey answers that measure some underlying factors. And Cronbach's alpha has a theoretical relation with factor analysis.

Table 4 Reliability statistics

\begin{tabular}{c|c}
\hline Cronbach's alpha & Number of items \\
\hline \hline .761 & 15 \\
\hline
\end{tabular}

Cronbach's alpha can be used as a function of the number of test items and the average inter-correlation among the items. a can take values between negative infinity and 1 . Generally, as a rule of thumb, it requires a reliability of 0.6 or higher. In this survey, a has the numerical value 0.76(Table4) and it means that this survey has internal consistency reliability.

From the above analysis, factors are extracted from 15 components and it may be summarized as follows.

The first factor includes these components like use of alternative fuels, incentives of pollution reduction, use of renewable-energy, dredging sand recycling and it can be named as ease the environmental burden.

The second factor is linked to these factors such as port facilities, and efficient equipment improvement, development of breakwater system of waterfront revitalization and it can be named as environment-friendly method \& technology development of construction

The third factor includes technical development of industry $\&$ the ocean waste disposal, resources recycling inside a port, introduction of port environment management system and it can be named as Utilization of resources\& waste inside a port.

The fourth factor includes introduction of port environment management system, expansion of the coastal region facilities, and efficient construction plan.

The last factor can be named as port redevelopment as waterfront belt and included components are modal shift as a eco-friendly system, establishing strategic plan for port environment \& introduction of environmental impact assessment, creation of artificial sandbar \& wetland.

From the above factor analysis result, five factors may be drawn about the green port indexes: (1) Ease the environmental burden (2) Environment-friendly method \& technology development of construction (3) Utilization of resources \& waste inside a port (4) Efficient planning \& management of port operation (5) Port redevelopment as waterfront belt

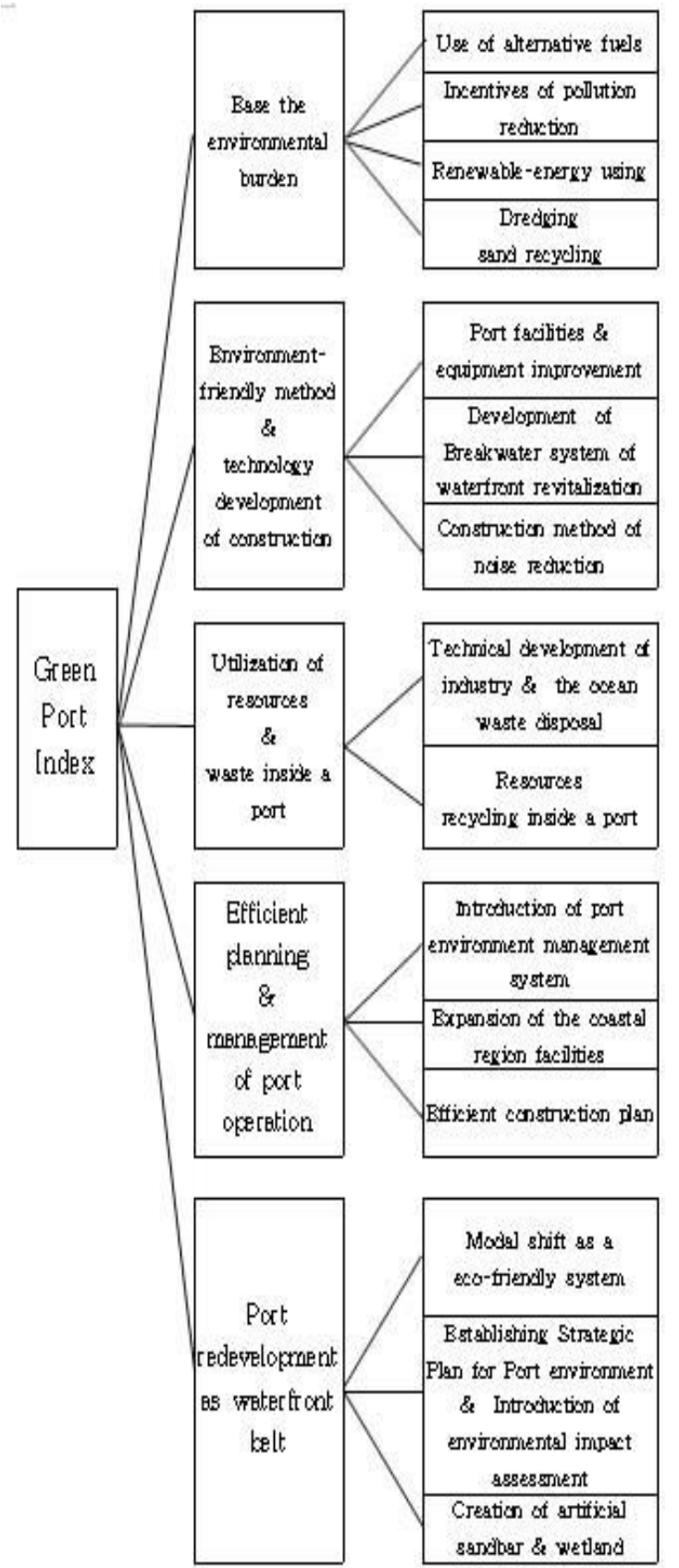

Fig. 2 Extracted 5 factors from 15 components

\section{Conclusion}

The ports are competing severely for securing a high position and competition is constantly accelerating. Especially, as the new trend in the 21st century is axed on environmental problems. Sustainable development and the ability to keep pace with a green port trend is one of the important points to succeed. For that reason, this paper laid the foundation for selecting the green port indexes and as a method, used factor analysis through the experts' survey. Factor analysis is a very effective method for reducing lots 
of factors about green port. 15 components were selected from the literature review and five factors were extracted by factor analysis. These five factors are as follow: (1) Ease the environmental burden (2) Environment-friendly method\& technology development of construction (3) Utilization of resources \& waste inside a port (4) Efficient planning \& management of port operation (5) Port redevelopment as waterfront belt.

This study gives a new light in recognizing the role of the ports and this light has not seen before in this field. On the one hand, it is a first attempt in driving green indexes by selecting the green port indexes. The present level of a port concerns the extent of green that can be revealed with these five factors.

The result of this study will point to several promising applications for further study. For this reason, the direction of upcoming study is going to evaluate the trading ports in Korea and other ports of the world with selected green indexes. Further study about evaluating trading ports in Korea will provide the new course understanding the new trend and the role of a port in the 21st century.

As a result, these five factors provide a stepping stone for developing as account of the green port.

\section{References}

[1] Ahn, G. H. and Lim, B. H. (2004), Social Research Method and analysis, hakhyunsa, pp304 317 .

[2] Bailey, D. and Solomon, G. (2004), "Pollution prevention at ports: Clearing the air", Environmental Impact Assessment Review.

[3] Hyun-dai engineering \& construction (2008), "Study on reducing carbon of ports".

[4] Jung, B, M. (2003), "The introduction of green marketing of ports", Marine and Fishery of monthly.

[5] Song, G. E. and Han, C. H. (2007), "A Study on the Strategies for the Reduction of Port Pollution", Journal of Korea Port Economic Association, Vol.23(1), 2007, pp.95 113 .

[6] Song, M. S. (2000), "Development plan for Eco-port", Korean Geo-Environmental Society".

[7] "Port of Long beach, (2009) Green Port Policy, www.polb.com".

Received 30 October 2009

Revised 18 December 2009

Accepted 21 December 2008 